\title{
The temple of Tulán-54: Early Formative ceremonial architecture in the Atacama Desert
}

\author{
Lautaro Núñez ${ }^{1, *}$, Isabel Cartajena ${ }^{2}$, Carlos Carrasco $^{3}$, Patricio López \\ Mendoza $^{4}$, Patricio de Souza ${ }^{2}$, Francisco Rivera ${ }^{5}$, Boris Santander ${ }^{6}$ \\ \& Rodrigo Loyola ${ }^{6}$
}

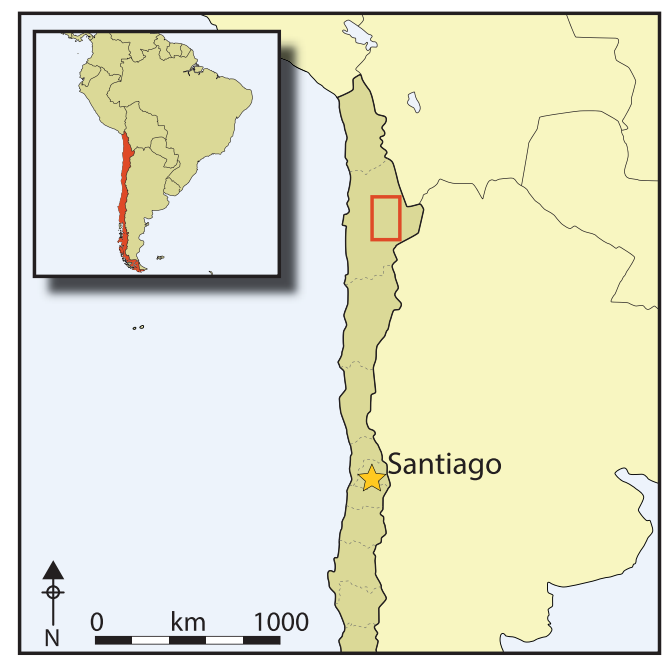

Unique among its kind in the Atacama Desert, the temple of Tulan-54 is a key site of the Early Formative period. Evidence of ceremonies and ritual activities, such as feasts and offerings, demonstrates that Tulan54 was the scene of important cultural and economic transformation, from huntergatherers to early pastoralist communities. Recent investigations have provided new data that enriches and challenges interpretations of the site, the association of its ceremonial architecture with its material culture, and its carved motifs and inhumations. This evidence expands our understanding of the social and cultural complexity of Chilean

Early Formative societies at both a local and regional scale.

Keywords: Chile, Atacama, Tulán, Early Formative period, temple

\section{Introduction}

Early Formative society (c. 3500-2400 BP) in the Tulán ravine is contemporaneous with the development of ceremonial and public architecture in the highlands of the Southern Andes. Sunken courts and ritual paraphernalia were used for feasting (cf. Dietler \& Hayden 2001) to strengthen local identities and reinforce status differentiation

1 Instituto de Arqueología y Antropología, San Pedro de Atacama, Universidad Católica del Norte, 380 Gustavo Le Paige, San Pedro de Atacama, Chile

2 Departamento de Antropologia, Universidad de Chile, 1045 Ignacio Carrera Pinto, Nuñoa, Chile

3 Colegio de Arqueólogos A.G., 378 San Antonio, Office 808, Santiago, Chile

4 Sociedad Chilena de Arqueología, 980 Grecia, Nuñoa, Santiago, Chile

5 Département d'anthropologie, Université de Montréal, Pavillon Lionel-Groulx, 3150 Jean-Brillant, Montréal, QC, H3T 1N8, Canada

6 Departamento de Antropología, Universidad Alberto Hurtado, 10 Almirante Barroso, Santiago, Chile

* Author for correspondence (Email: lautaro.nunez@hotmail.com) 
within the emergent elite (Stanish 2003; Hastorf 2003, 2008; Ikehara \& Shibata 2005; Pollock 2015). In the southern Titicaca basin, the growth of Chiripa-an early village society - was associated with the development of a set of religious practices and public ritual activities (Bandy 2006; Moore 2014). The villagers depended on flexible subsistence strategies based on a combination of horticulture, fishing and other lacustrine resources, small-scale camelid herding and the gathering of wild resources (Bandy 2006; Moore 2014).

Other interpretations of contemporaneous Formative societies have recently been proposed. In the Southern Andes, those societies invested neither in sedentary villages nor in public architecture. The Wankarani cultural complex (Bolivian highlands-north-east Poopo Lake) is characterised by large mounds resulting from superimposed episodes of occupation. These mounds, some of which contained burials, were originally interpreted as agricultural settlements (Ponce Sanginés 1970; Capriles 2014 and references therein). They seem, however, to have related to early mobile herding communities, whose settlement patterns included residential bases that were repeatedly used as seasonal pasture areas. Some of these settlements could have hosted different groups and ritual activities (Capriles 2014).

Abundant evidence in the Tulán ravine, south-east of Salar de Atacama, has confirmed an intricate local process of increasing complexity during the Late Archaic and Early Formative transition (c. 3800-3400 cal BP) (Núnez et al. 2006). Increasing humidity at the end of the Late Holocene permitted greater social aggregation, especially in eco-refuges, defined as particularly favourable locations for human habitation (Grosjean \& Núñez 1994; Núñez et al. 2013).

Early Formative groups developed a mixed economy sustained by hunting, gathering and camelid breeding. While integrating an important ritual component directly merged with economic and technological aspects, these communities developed a pattern of fixed and mobile subsistence. This facilitated the exploitation of several micro-environments using different strategies and inter- and intra-regional exchange. The Tilocalar phase, dating to c. 3360-2370 cal BP, is well represented by three important settlements (Tulán-54, 85 and 122). These are located within a $30 \mathrm{~km}$ area between the border of the Salar de Atacama and the Tulán ravine, at an altitude ranging from $2300-3200 \mathrm{~m}$ (Figure 1A). These sites have different functions (Núnez et al. 2006). At Tulán-122, located in the middle sector of the ravine, residential aspects were emphasised. In contrast, Tulán-85, located on the border of the resource-rich salt flat (López et al. 2013), contained few residential structures but comprised an extensive and deep refuse mound resulting mainly from production activities. The Tulán-54 site, located in the upper part of the ravine, represents a ceremonial centre with monumental architecture and burials (Figure 1B). This site could be considered as a local political and religious centre. Furthermore, it shows the integration of macro-regional interaction networks (Núnez et al. 2017).

The entire site covers an area of approximately $8000 \mathrm{~m}^{2}$. The terrain at Tulán54 is formed by an extensive mound, which overlays several areas of accumulation and structures. The recent archaeological research programme at Tulán-54 carried out geophysical surveys (ground-penetrating radar) and intensive excavations in different areas 


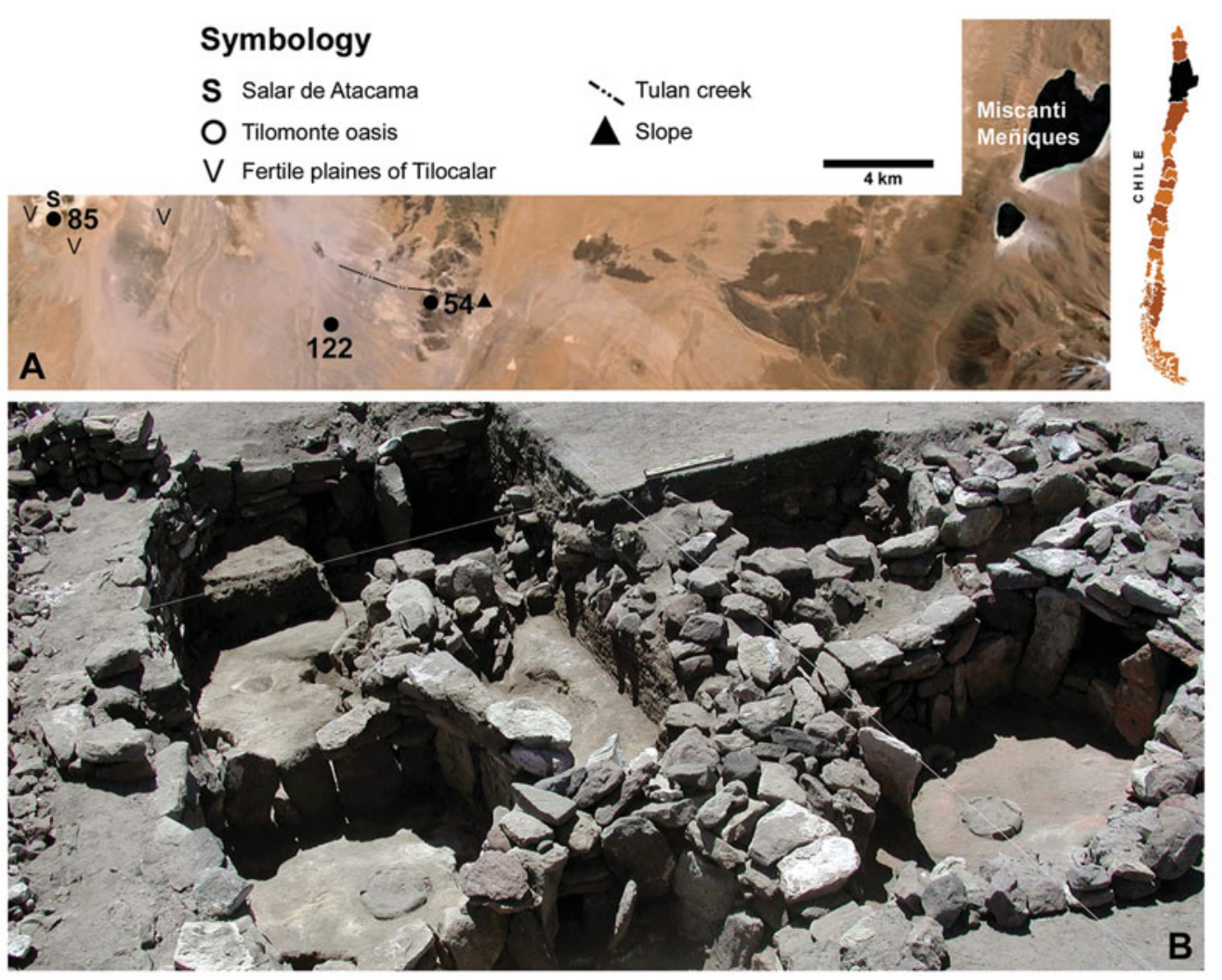

Figure 1. A) Location of the Tulan ravine and sites identified along the transect (image by Google Earth); B) general view of the ceremonial structure.

of the site, including its periphery (Núñez et al. 2016). New architectural and burial features were identified on a much larger scale than previously known. In addition to the previously identified central semi-subterranean ceremonial structure, a smaller contemporaneous one was discovered. This smaller structure was initially considered to be a separate building. Yet a pattern of connected walls between both structures emerged, thus revealing a complex ceremonial architectural layout (Figure 2). Rudimentary stone structures relating to non-permanent domestic activities were identified. Finally, an arrangement of large horizontal slabs (resembling a seal but of unknown function) was discovered in the area surrounding the temple, at the level of the perimeter wall.

This new evidence prompted a re-evaluation of the site as a ceremonial centre with a variety of functions. This article focuses on the central semi-subterranean ceremonial structure and how its architectural characteristics and scale, and its peculiar features and associated material, emphasise the relationship of architectural evidence with repetitive and ritual activities. 


\section{Symbology}

A, B, C, D, E and F: Structures

$F$ : Structured and opened fireplaces

$\triangleright$ : Petroglyphs in structures $N^{\circ} s 1,2$ y 3

- : Incisions in structures

$\Rightarrow$ : Niche in wall perimetral

: Petroglyphs $\mathrm{N}^{\circ} \mathrm{s} \mathbf{4}$ and 5

6 :

Tombstone on newborn in pit

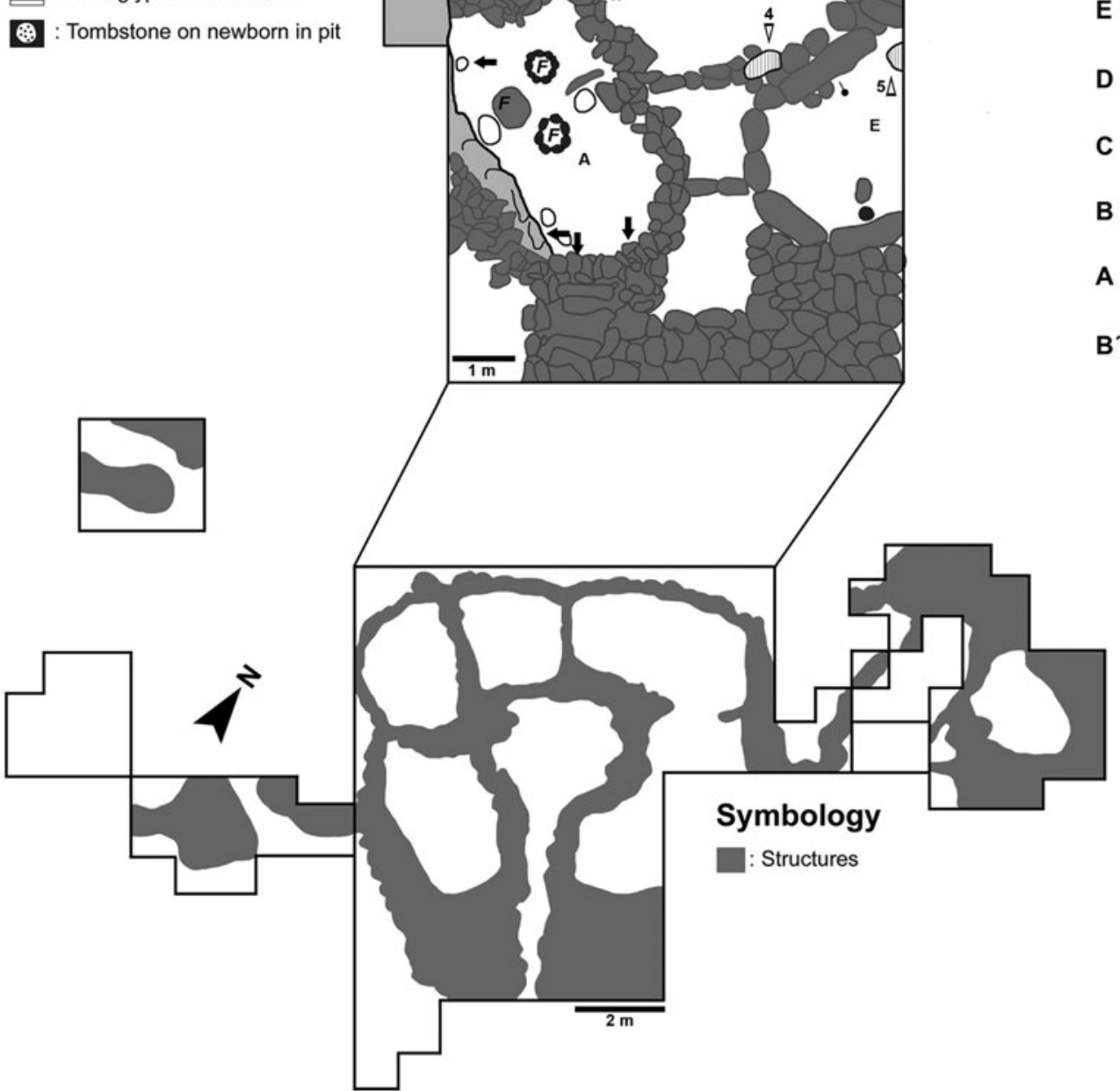

Figure 2. Plan of the Tulán-54 ceremonial structure.

\section{The Tulán temple}

The central temple covers an area of about $2800 \mathrm{~m}^{2}$. The archaeological excavations conducted within comprised a total of $98 \mathrm{~m}^{2}$. The structure was intentionally filled by debris (C) Antiquity Publications Ltd, 2017 
(to a maximum depth of around $2 \mathrm{~m}$ ) during occupation, until it was completely covered (Núñez et al. 2017). One of the most distinctive features of the temple is its surrounding perimeter wall, built with large blocks arranged vertically and which also contains niches that are topped by lintels (Núñez et al. 2006). The temple was constructed sequentially. First, the floor was dug out and the vertical blocks of the perimeter wall were arranged.

The inner space was then divided into six enclosures, five delimited by the perimeter wall and one oval structure in the middle. The interior precinct separation walls were erected with flatter blocks and semi-edged stones, supported by stone wedges. Inside all the enclosures and adjacent to the perimeter wall, 27 graves containing human infant inhumations were excavated (Figure 2). Most of the graves were covered by stone slabs and contained sophisticated offerings or prestige goods, although no offerings were found in three of the graves. Bowl-shaped pit hearths, some of which were delimited with stones and others without delimitation, were found within the precincts and close to the burials. Finally, blocks with zoomorphic, anthropomorphic and linear incisions were recorded, along with pictographs of red naturalistic camelids (Núñez et al. 2006).

Three sub-phases were identified and dated. Sub-phase I, dating from 3360-2950 to $3170-2930 \mathrm{cal}$ BP, corresponds to the beginning of the occupation. The main structure of the temple was built during sub-phase II, with infant burials occurring from 3050-2770 to 2870-2740 cal BP. During occupation of the temple, refuse layers continually filled the precincts, resulting in a well-defined stratigraphy. A mound was formed in the central precinct by successive thin strata containing lenticular hearths with inorganic residues. In the precincts attached to the perimeter wall, thick continuous strata interspersed with ash lenses were formed, among others containing abundant bones, and lithic sand pottery refuse. Sub-phase III, dated to between 2870-2740 and 2410-2370 cal BP, was defined by the stratigraphic accumulation and architectural changes that took place as the temple was completely covered and its activities ceased (Núñez et al. 2011) (Figure 3).

\section{Recovered materials}

The ceramic assemblage from the Tulán temple corresponds to the Los Morros type, which is recurrent in the Atacama Salar and the upper and middle Loa River area. This Early Formative ceramic is characterised by a coarse temper, comma-shaped edges, an absence of handles, convex bases, polishing and smoothing finishing techniques, and, in some cases, corrugated incisions and impressed nail decorations (Benavente 1978; Tarragó 1989; Thomas et al. 1995; Sinclaire et al. 1998; Ayala \& Uribe 2003).

The Los Morros A type from the Early Formative period is characterised by a paste rich in large- to medium-sized inclusions $(0.5-3.5 \mathrm{~mm})$. A smoothing and polishing treatment is applied to both the inner and outer surfaces. In some cases, cracks around the inclusions are visible (Kalazich 2006; Varela 2011) (Figure 4A). The vessels were manufactured using the coiling technique. Restricted shapes predominate, corresponding to inflected vessels of everted edge. Most vessels are large, with a diameter exceeding $160 \mathrm{~mm}$. Traces of soot in some of these vessels suggest that only a few were used in cooking; most of them were used for serving and storage, although some open forms could have contained pigments (Kalazich 2006). 
OxCal v4.2.4 Bronk Ramsey (2013); r.5 SHCal13 atmospheric curve (Hogg et al. 2013)

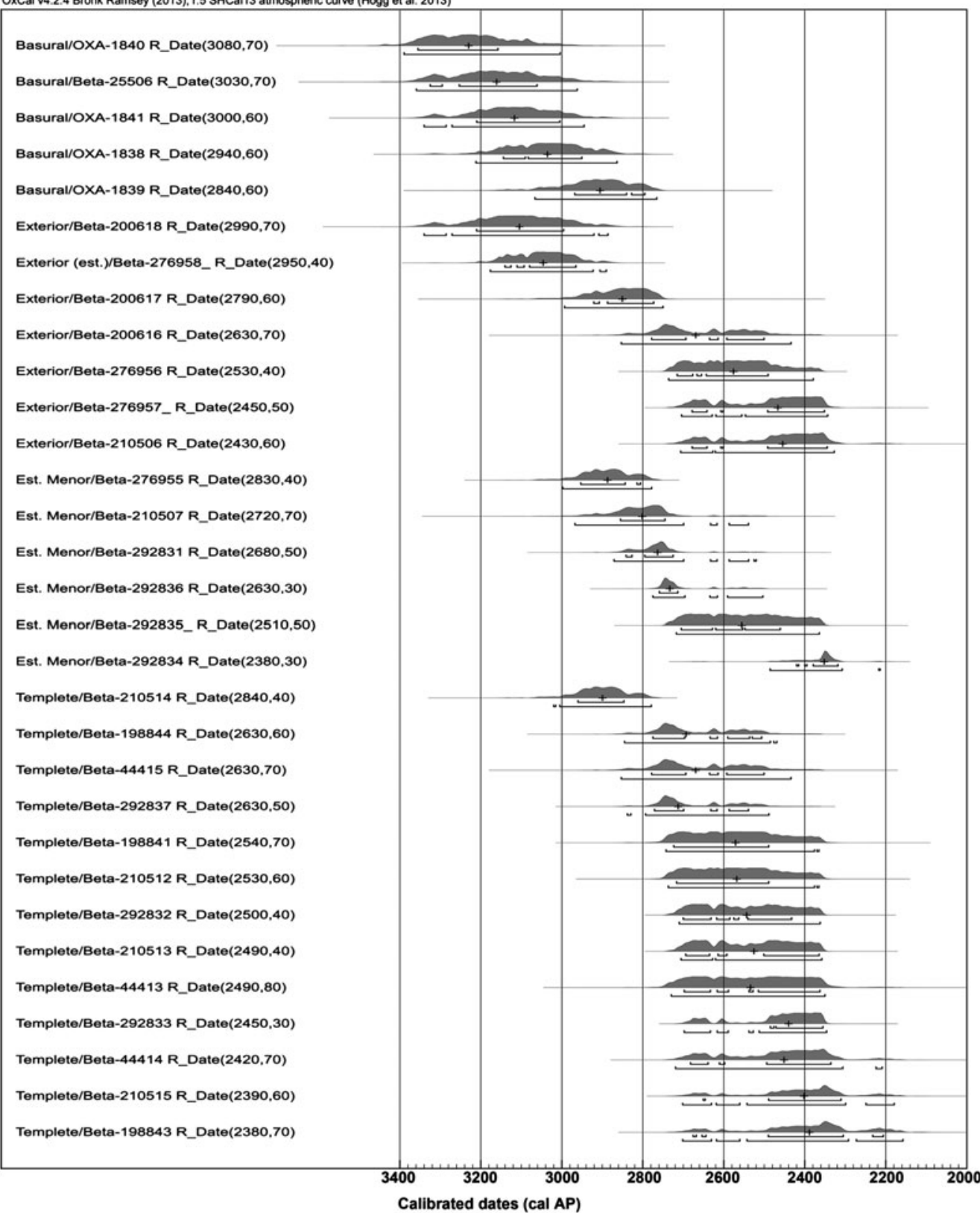

Figure 3. Calibrated dates obtained from the different sectors of the Tulán-54 site (refuse area outside of the ceremonial structure, outside structures and main ceremonial structure (temple)) (taken from Núnez et al. 2017). Calibrated with OxCal 4.2 (Bronk Ramsey 2009), curve SHCal13 (Hogg et al. 2013).

(C) Antiquity Publications Ltd, 2017 

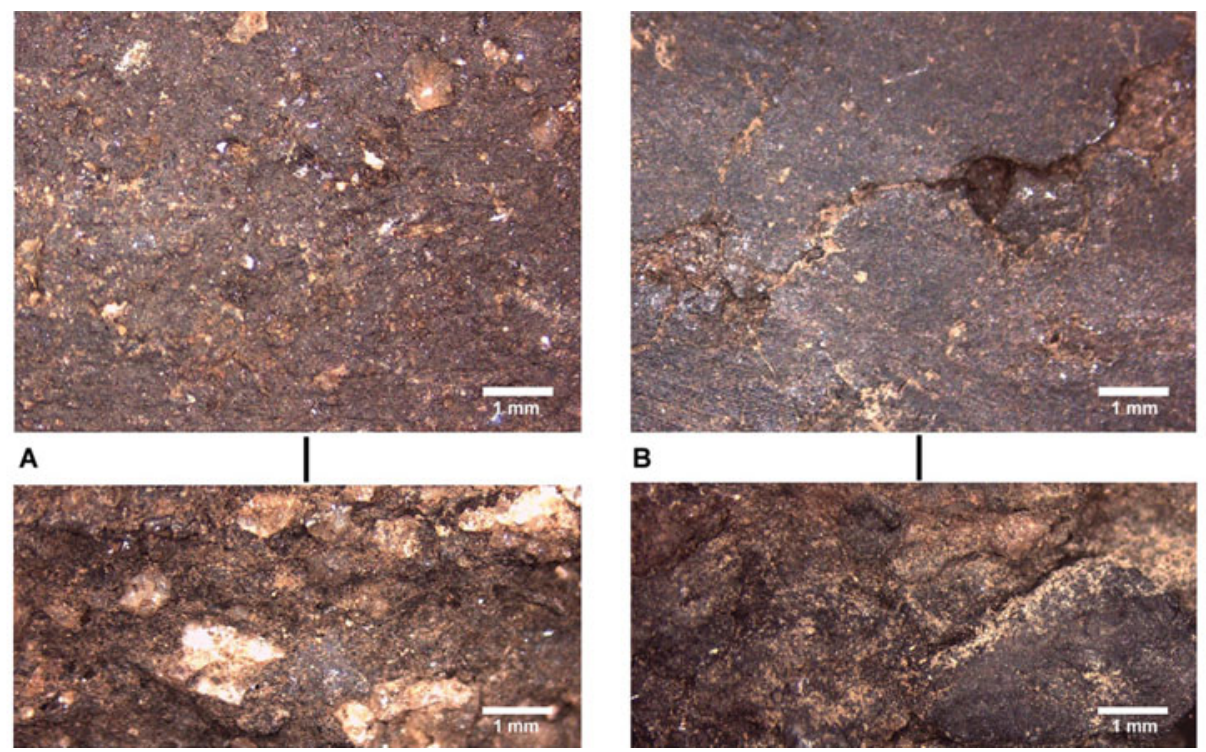

Figure 4. A) Los Morros A pottery, surface and cross section; B) Los Morros B1 pottery, surface and cross section.

A second ceramic type corresponds to Los Morros B1, which is predominated by inclusions of thick white aggregates, clear quartzite, translucent quartz and gold mica, of thin to medium sizes $(0.2-1.8 \mathrm{~mm}$, Varela 2011) (Figure 4B). Smoothing prevails for the inner and outer surface treatment, but polishing is occasionally observed. Restricted shapes dominate, with diameters suggesting the presence of both small and large vessels $(40-210 \mathrm{~mm})$. In some cases, handles are attached to the lip. Soot is, however, more frequently observed and still confined to large vessels. Remaining vessels may have been used for food and/or liquid storage (Kalazich 2006). The Los Morros B2 type represents a variation within the Los Morros assemblage. It is related to small and straight-edged vessels, which contain smaller inclusions (Kalazich 2006). Furthermore, fragments of tubular pipes and intrusive ceramic (with rope impression, fingernail and imbricated decorations) indicate connections with the lowlands of north-western Argentina (Kalazich 2006).

The lithic assemblage is dominated by micro-drills. These are associated with a prolific bead and pendant industry, the products of which were mainly manufactured out of copper minerals but also shells. Less frequently represented are knives, scrapers, projectile points, multifunctional blades, preforms and prepared cores. Tuffs and other coarse-grained rocks are available within $5 \mathrm{~km}$ of the site, and were used to produce knives, scrapers, sidescrapers and, to a lesser extent, bifacial tools. This highlights the presence of an important blade industry, brought to the site at the final stages of its reduction sequence. The sources of siliceous stone have not yet been found. It is, however, assumed that these would originate from the lowlands or 'pampa' ( $80-100 \mathrm{~km}$ distant, at $1000 \mathrm{~m}$ asl), where sources of siliceous rocks and chalcedony have been identified (Borie 2015). Siliceous rocks were transported as unipolar flake-cores and blanks, which were used to produce micro-drills; obsidian has also been identified. Trace element analyses have revealed a stable flow of raw material from the Atacama highlands (>4000m asl) and from the Argentinian Northwest in the Andean 
eastern flank (Escola et al. 2005). Many of the projectile points were made from obsidian. Pedunculated points occur most frequently, but lanceolate and triangular ones were also found; some could have been hafted to arrows, spears or spear-thrower darts (de Souza 2004). Interestingly, some of the projectile points were never used.

Large quantities of lapidary-produced beads were recovered in association with microdrills and mineral waste. Copper ore beads are mostly discoidal-shaped with an average diameter of around $6 \mathrm{~mm}$ and a rectangular section. A few tubular beads were also recovered (Soto 2006; Figure 5D). In addition, gold, lead and copper objects were found, some of which were embossed to create anthropomorphic and zoomorphic figures (Figures 5A \& B).

The faunal assemblage comprised mostly camelid bones. Osteometric analyses revealed the presence of two wild species: guanaco (Lama guanicoe) and vicuña (Vicugna vicugna). A domestic species, llama (Lama glama), was also identified. Although most elements were fused (indicating adult animals), the number of young animals-especially of newborn camelids-was greater (35 per cent) inside than outside the structure (Cartajena et al. 2007). The higher representation of young animals could relate to ritual activities inside the temple. Body segments are differentially represented, suggesting the intentional selection of anatomical units for consumption and disposal. The most frequently represented elements are from the pectoral and pelvic girdle, lower extremities (metapodials, carpals, tarsals and phalanges), and heads. Other elements are poorly represented, despite the recovery of all body segments. The selectivity of anatomical units shows that the most abundant units provide only moderate meat, marrow or grease (Núnez et al. 2017), but were symbolically important in the Andean world and received special treatment. The long-term accumulation of bones in the different precincts could suggest that their disposal followed prescribed rules or norms. It also may have resulted from not only in situ consumption, but also from intentional disposal following activities external to the temple. Some of these bones could have been associated with tool-making activities, as suggested by the frequent use of metapodials in textile production (cf. Santander 2014). A small percentage of the faunal assemblage represents rodents, such as Ctenomys sp., Phyllotis sp., Lagidium viscacia and Chinchilla brevicaudata, and birds (e.g. Metriopelia sp. and Phoenicopteridae) (Labarca 2005). Although rodents and birds were complementary resources, it is not possible to rule out their ritual use (Eeckhout 2004), especially for those elements found burnt in fireplaces.

Archaeobotanical evidence indicates exploitation of wild local resources, such as Opuntia sp., Scirpus sp., Atriplex sp., Catholippia riojana, Cortaderia atacamensis and Prosopis sp., among others (McRostie 2007, 2013; Núnez et al. 2009a). Milling practices are associated with the collection and grinding of wild plants for consumption, but these plants were also used as fuel and cordage (Holden 1991; McRostie 2007, 2013; Núñez et al. 2009a). Evidence for horticultural practices is rare and these are represented by scant remains of quinoa (Chenopodium quinoa), maize (Zea mays) and cucurbits (Lagenaria sp.). Maize has been identified from starch grains on lithic tools (Babot 2004), but its low frequency does not suggest production on a large scale. Starch extracted from a metate (milling stone) associated with one infant burial indicates the presence of Anadenanthera sp., a taxa consumed for its psychotropic properties (Andreoni \& Capparelli 2007; McRostie 2013).

(C) Antiquity Publications Ltd, 2017 

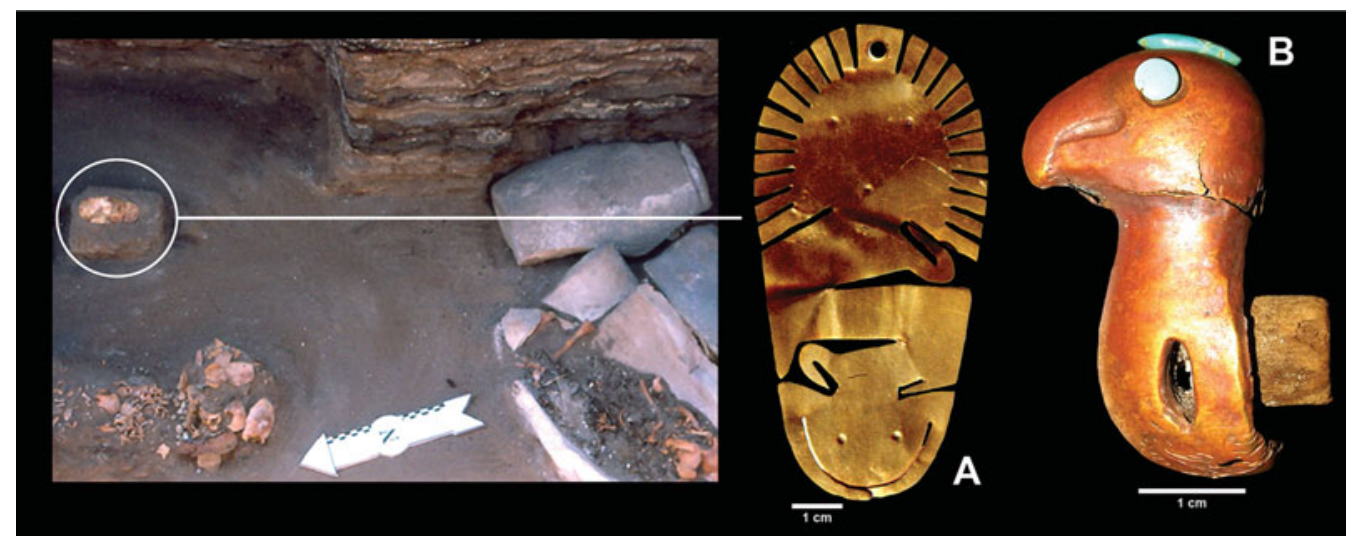

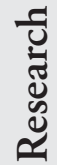
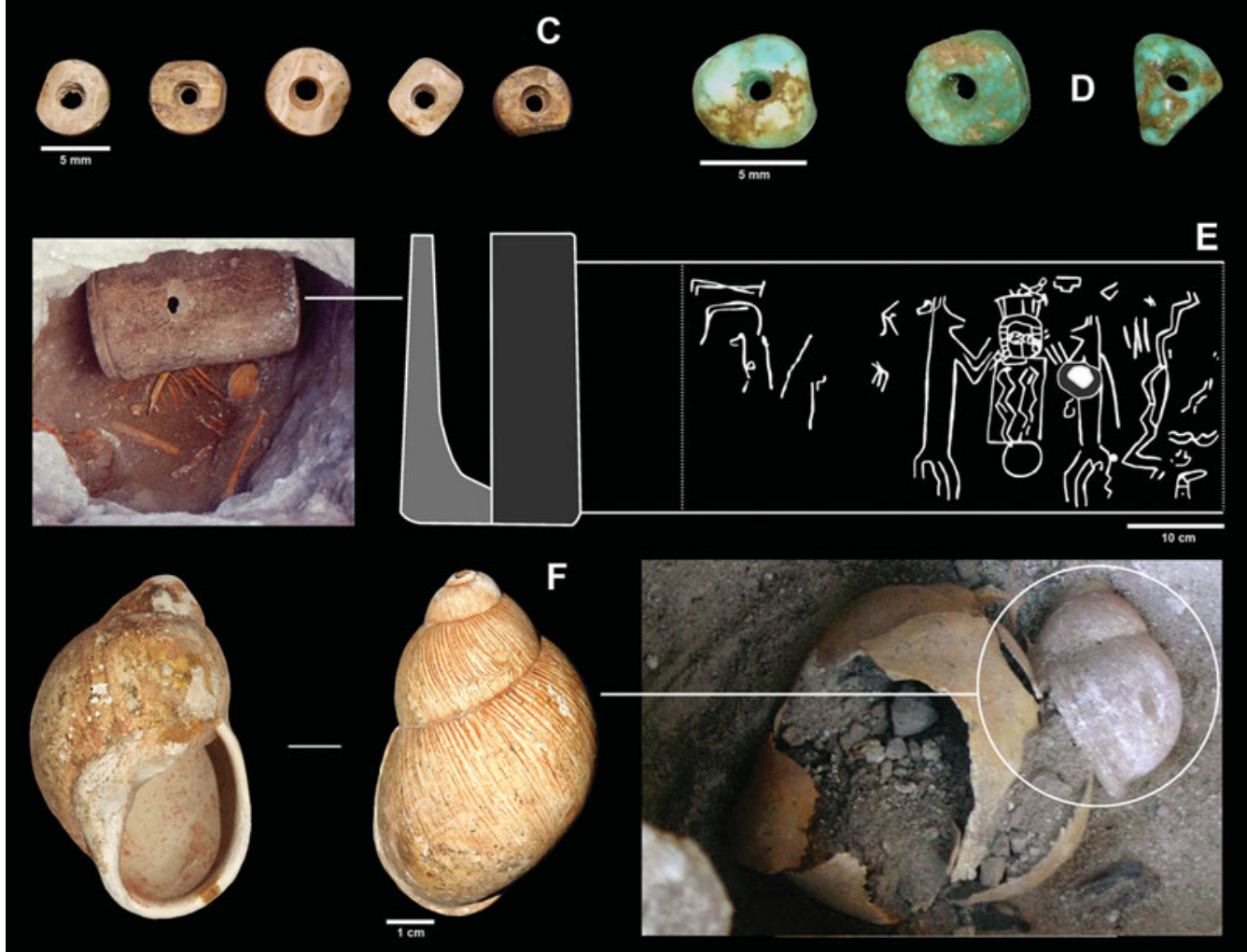

Figure 5. A) Perforated gold leaf with two facing embossed heads, deposited as an offering at the C13 burial (D unit); B) embossed condor gold head covering a wooden matrix, with copper inlay in the comb and in one eye cavity; $C)$ shell beads; D) copper beads; E) engraved stone vase as offering at the double burial in the D unit; F) Strophocheilus oblongus in situ.

\section{Ritual architecture}

The central temple of Tulán-54 was designed to house selective and recurring activities within its enclosures. A ramp was built at the entrance, forming a small corridor that descends into the temple and restricts access. In the initial phases of activity, ceremonial 

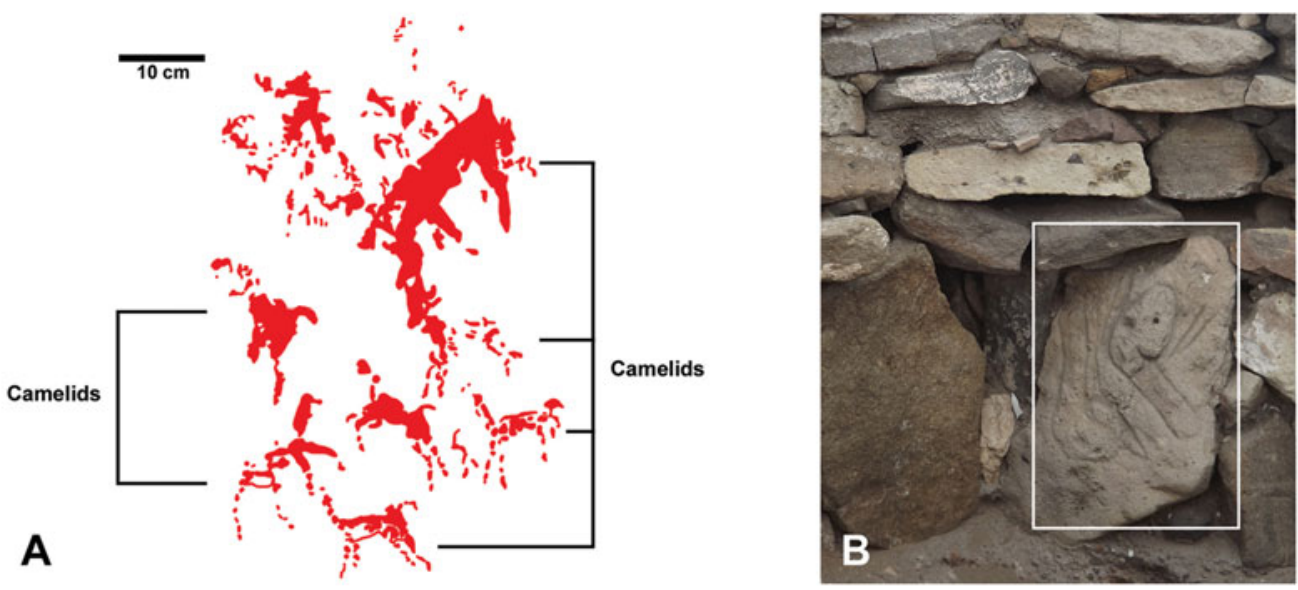

Figure 6. A) Confluencia-style pictographic representations of camelids located inside the central ceremonial structure (image by Wilfredo Faundes); B) general view of the perimeter wall and of the engraved head of a camelid on one of the blocks.

activities were focused on the burial of 27 infants, which were interred individually, except for a double and a triple inhumation. All bodies were placed lying on their right side (Núñez et al. 2006). Grave offerings, consisting of necklaces and prestigious objects, were then placed on the thoraxes and skulls of the infants. The graves were sealed with horizontal slabs, and then back-filled with soil. Although most of the infants were aged 6-12 months at death, two were between 2 and 4 years of age. There was also one foetus (Costa 2005).

Among offerings associated with two particular inhumations were intentionally perforated and broken (i.e. matados, meaning ritually 'killed') engraved stone goblets (Figure 5A). One goblet, placed in the temple's central precinct, was engraved with an anthropomorphised camelid. The other, found in enclosure $\mathrm{D}$, depicts two erect camelids facing a character arranged at the centre (Figure 5E). Gold objects were also used as burial offerings. One of them, also from precinct $\mathrm{D}$, is a perforated gold leaf with two facing embossed heads (Figure 5A). Another, a wooden cap covered with the embossed gold head of a condor, was placed in the mouth of one of the infants (Figure 5B). Finally, snail shells from the eastern Andean lowlands were also used as offerings (Figure 5F). The burials of individuals C4 and C5 were dated to 2850-2720 cal BP (charcoal); the burial of the individual C1 dated to 2760-2340 cal BP (charcoal), and individual C10 dated to 27802370 cal BP (bone) (Núnez et al. 2017). Thus, the dated infants were all buried within a short time frame.

Ritual activities are manifest in different types of pictographs and carved motifs that were found on the interior stone walls of the temple. Examples include small red pictographs arranged on a single stone block that represent a group of camelids in motion (Figure 6A). A full-scale camelid head petroglyph (Figure 6B) and parallel incisions were recorded on one perimeter wall block. A new carved motif was recorded on other inner precinct blocks. This represents a figure carrying a dart, and a camelid with a rope around its neck. The rock art replicates two well-known regional styles: the naturalistic engraved camelids of Taira-Tulán, and the red pictographs of Confluencia (Berenguer 2004; Núnez et al. 2009b).

(C) Antiquity Publications Ltd, 2017 


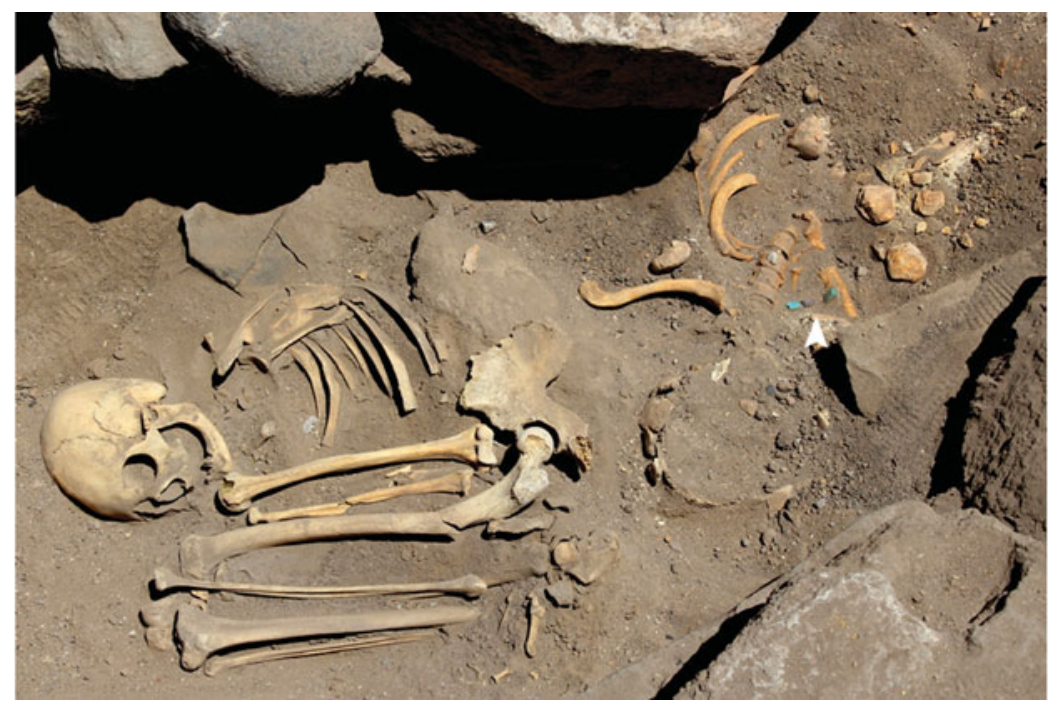

Figure 7. Burial structure containing two adults next to the temple structure. The white arrow indicates the position of beads near the neck of one of the individuals.

Further evidence of ritual activity is the frequent use and abandonment of hearths, during occupation. These were associated with pottery containers, grinding implements, animal bones and abundant copper particles. The presence of burnt and calcinated bones within the hearths suggest ceremonial meals and offerings. These remains could be interpreted as representing traditional Andean rituals, where offerings and aromatic and resinous plants are burned in fire embers (Rösing 1994).

In contrast to the richly furnished infant graves inside the ceremonial structure, outside burials without offerings were recorded under stone accumulations. One burial, located west of the temple, contained an adult lying on his right side in a semi-flexed position, with no associated offerings or objects. Another adult, buried adjacent to the former individual, had tubular beads placed on the neck area (Figure 7). A third adult without associated offerings was found farther to the east in a grave disturbed by concurrent inhumations (Núñez et al. 2017).

\section{Interpreting the evidence}

The ceremonial architecture of the temple has a well-understood place in Late Archaic period research. Features such as the large vertical wall blocks, niches, lintels, pits and blocks engraved with parallel lines, are well documented since 4870-4540 cal BP. Recurrent occupational deposition filled the structures until they were completely covered (Núnez et al. 2006). Thus, Tulán ravine offers an insight into the emergence and development of southern Andean social and ritual complexity from the Late Archaic to the Early Formative period. At Tulán, a southern ceremonial transitional pattern emerged from complex huntergatherer communities to early pastoralism economies, where ceremonial architecture shows great differences in scale and the incorporation of new features, rock art and inhumations.

(C) Antiquity Publications Ltd, 2017 
Many of the rituals could be linked to the development of a local leadership oriented towards the integration and cohesion of emergent herder communities, founded perhaps on kinship, as a way of ensuring communal, family and/or individual rights (Capriles 2017). During the Early Formative period, societies and the economy experienced profound transformations, which could have required religious support necessary to confront risks inherent in the emergence of a new way of life. The presence of offerings in the temple reflects recurrent pan-Andean ritual activities, also identified in other Archaic-Formative ceremonial sites of the central Andean coast (Makowski 2005). They were usually associated with pleas and acts of gratitude, for successful livestock breeding and protection during travel, among other things (Rösing 1994). Periodic congregations that feasted and honoured ancestors along the Circumpuna Andes share common features, such as infant burials accompanied by offerings, offering pits and the ceremonial architecture in which these rituals were performed (e.g. Bennett 1936; Ponce Sanginés 1970; Beck 2004).

In Tulán, the occurrence of what appear to be ritual activities can be more plausibly interpreted as methods to foster bonds of reciprocity with tutelary beings. These beings represented the ancestors and owners of the community, livestock and rain, to whom food, sacrifices and rogations were offered-as observed today in ethnic enclaves (Fernández 1994). At Tulán, the emphasis on infant inhumation represents foundational acts associated with access to numen and ancestral powers, the infants acting as intermediaries to the Andean pantheon. It is not clear whether the infants died a natural death. Although there is no osteological evidence of trauma (Verano 2001), their similar ages, simultaneous burial and ritual contexts suggest sacrificial rites.

From one generation to another, specific lineages would have been invested with an important role as religious leaders. They were also the ones who would have mitigated possible conflicts derived from incipient inequality. Restricted access to the temple interior, as well as its small inner space that would have limited circulation, suggests that repeated ritual activities in every precinct were performed by small numbers of people. The Tulán ceremonial centre shows a different scale in comparison to the large congregations and feasts in the Andean highlands. The ones that may have occurred in Tulán were smaller than competitive feasts, being of a more local and communal nature (Dietler \& Hayden 2001; Roddick 2002; Stanish 2003; Dillehay 2005; Ikehara \& Shibata 2005; Hastorf 2008).

The rites that took place inside the temple suggest the presence of two levels of social integration. The first was oriented towards the local community. The lack of a village settlement at Tulán-54 suggests that the site could have been a congregation place for the ritual activities of local groups occupying the Tulán ravine. Vessels relating to the preparation and service of food and liquids are absent from all of the occupation phases. The presence of large vessels and pipes suggests that these events were performed on a communal scale (Kalazich 2006). The debris that filled the structure is very similar to that found in the other sites. Well-defined and foreign objects, such as pipe fragments, imbricate pottery and psychotropic plant remains were probably used as paraphernalia for ritual activities.

The offerings accompanying the infant burials have a widespread Early Formative distribution: from the Pacific coast to the eastern slope of the Andes, and farther north to Tarapacá, where they were occasionally found in isolated funerary contexts (Núñez et al. 2006a \& b; Núnez \& Santoro 2011; Gallardo \& Cabello 2015). Correspondingly,

(C) Antiquity Publications Ltd, 2017 
connections with the Pacific coast, the Loa River and north-western Argentina intensified during the Tilocalar phase. This is expressed by the presence of turbans (textile headwear), of Los Morros ceramics, of Pacific and western shells, and of copper objects, among others (González \& Westfall 2010; Pimentel et al. 2011).

The prestigious goods and different rock art styles found inside the temple structure raise the question of the extent to which groups who inhabited the Tulán ravine shared a common ideology, at both the regional and macro-regional levels. In this context, a set of ideas-widely spread in a multi-directional flow-permitted and validated the rise of a proto elite in Tulán, which controlled ritual activities and large-scale bead production. This is a well-documented phenomenon, observed in all Early Formative sites on the south-east border of the Salar de Atacama basin.

The temple could have been conceived as a foundational social centre, which was gradually and intentionally filled over time, mainly as a result of ritual activities. Once it was completely covered, the site was abandoned. Today, however, the site is still known by the local community as the place where the ancestors feasted together.

\section{Acknowledgements}

The authors are grateful to the Atacameña community of Peine for their cooperation. This research was funded by the FONDECYT 1130917 project.

\section{References}

Andreoni, D. \& A. Capparelli. 2007. Compilation of plants involved in the use of South American pipes: a contribution to archaeobotanical contrast, in A. Bieniek (ed.) Programme and abstracts of the $14^{\text {th }}$ Symposium of the International Work Group for Palaeoethnobotany: 105. Kraków: W. Szafer Institute of Botany, Polish Academy of Sciences.

Ayala, P. \& M. Uribe. 2003. La cerámica Wankarani y una primera aproximación a su relación con el período Formativo del Norte Grande de Chile. Textos Antropológicos 14(1): 7-30.

Вавот, M.P. 2004. Tecnología y utilización de artefactos de molienda en el Noroeste prehispánico. Unpublished PhD dissertation, Universidad Nacional de Tucumán.

BANDy, M. 2006. Early village society in the Formative period in the southern Lake Titicaca Basin, in W.H. Isbell \& H. Silverman (ed.) Andean archaeology III. North and south: 210-36. New York: Springer. https://doi.org/10.1007/0-387-28940-2_10

Beck, R.A., JR. 2004. Architecture and polity in the Formative Lake Titicaca basin, Bolivia. Latin American Antiquity 15: 323-43. https://doi.org/10.2307/4141577
Benavente, M.A. 1978. Chiuchiu-200: poblado agroalfarero temprano. Revista Chilena de Antropología 1: 5-15.

BennetT, W.C. 1936. Excavations in Bolivia. Anthropological Papers of the American Museum of Natural History 35: 329-507.

Berenguer, J. 2004. Cinco milenios de arte rupestre en los Andes atacameños: imágenes para lo humano, imágenes para lo divino. Boletín del Museo Chileno de Arte Precolombino 9: 78-80.

Borie, C. 2015. Una aproximación desde las tecnologías geoespaciales a la identificación de fuentes líticas primaras al interior de la costa arreica de Taltal. Estudios de los espacios internodales y su aporte a la historia, naturaleza y dinámica de las ocupaciones humanas en zonas áridas. Paper presented in the XX Congreso Nacional de Arqueología Chilena, October 5-9, Concepción.

Bronk Ramsey, C. 2009. OxCal 4.2. Available at: http://c14.arch.ox.ac.uk/oxcal (accessed 10 April 2017).

Capriles, J. 2014. Mobile communities and pastoralist landscapes during the Formative period in the central Altiplano of Bolivia. Latin American Antiquity 25: 3-26. https://doi.org/10.7183/1045-6635.25.1.3

- 2017. Arqueología del pastoralismo temprano de camélidos en el Altiplano central de Bolivia. La Paz: Institut Français d'Études Andines. 
Cartajena, I., L. Núñez \& M. Grosjean. 2007. Camelid domestication in the western slope of the Puna de Atacama, northern Chile. Anthropozoologica 42: 155-73.

Costa, M.A. 2005. Informe de determinación de edad de individuos infantiles del sitio Tulán-54. Informe 1 y 2 de avance. Report prepared for Fondecyt 1020316, Santiago.

DE Souza, P. 2004. Tecnologías de proyectil durante los períodos Arcaico y Formativo en el Loa superior (Norte de Chile): a partir del análisis de puntas líticas. Chungara 36: 61-76.

Dietler, M. \& B. Hayden. 2001. Feasts: archaeological and ethnographic perspectives on food, politics, and power. Washington, D.C.: Smithsonian Institution.

Dillehay, T. 2005. Introducción. Boletín de Arqueología PUCP 9: 19-24.

Eескноuт, P. 2004. Relatos míticos y prácticas rituales en Pachacamac. Boletín de Instituto Francés de Estudios Andinos IFEA 33(1): 1-54. https://doi.org/10.4000/bifea.5786

Escola, P., L. NúŃEz \& S. Hocsman. 2005. Distribution and circulation of obsidian in Puna de Atacama (ca. 4500-3000 AP). Report prepared for Fondecyt 1070040, Santiago.

Fernández, G. 1994. El banquete aymara: aspectos simbólicos de las mesas rituales aymaras. Revista Andina 12: 155-90.

Gallardo, F. \& G. Cabello. 2015. Emblems, leadership, social interaction and early social complexity: the ancient Formative period (1500 BC-AD 100) in the desert of northern Chile. Cambridge Archaeological Journal 25: 615-34. https://doi.org/10.1017/S0959774315000013

GonzÁlez, C. \& C. Westrall. 2010. Cementerio Regimiento Chorrillos de Calama: testimonios funerarios formativos en el Loa medio, región de Antofagasta, in Sociedad Chilena de Arqueología (ed.) Actas del XVII Congreso Nacional de Arqueología Chilena Tomo 1: 95-105. Valdivia: Universidad Austral de Valdivia.

Grosjean, M. \& L. NúñEz. 1994. Late glacial, early and middle Holocene environments, human occupation, and resource use in the Atacama (northern Chile). Geoarchaeology 9: 271-86.

Hastorf, C.A. 2003. Community with the ancestors: ceremonies and social memory in the Middle Formative at Chiripa, Bolivia. Journal of Anthropological Archaeology 22: 305-32. https://doi.org/10.1016/S0278-4165(03)00029-1

-2008 . The Formative period in the Titicaca basin, in H. Silverman \& W.H. Isbell (ed.) Handbook of South American archaeology: 545-61. New York: Springer.
Hogg, A.G., Q. Hua, P. Blackwell, M. Niu, C. Buck, T. Guilderson, T. Heaton, J. Palmer, P. Reimer, R. Reimer, C. Turney \& S. Zimmerman. 2013. SHCal13 southern hemisphere calibration, 0-50,000 years cal BP. Radiocarbon 55: 1889-903. https://doi.org/10.2458/azu_js_rc.55.16783

Holden, T.G. 1991. Evidence of prehistoric diet from northern Chile: coprolites, gut contents and flotation samples from the Tulán quebrada. World Archaeology 22: 320-31. https://doi.org/10.1080/00438243.1991.9980149

Ikehara, H. \& K. Shibata. 2005. Festines e integración social en el periodo formativo: nuevas evidencias de Cerro Blanco, valle bajo de Nepeña. Boletín de Arqueología PUCP 9: 123-59.

Kalazich, F. 2006. Tipología y contextos de uso de la alfarería temprana de Tulán y Puna de Atacama. Unpublished professional practice dissertation, Universidad de Chile.

LABARCA, R. 2005. Zooarqueología de fauna menor en la Puna Salada: el caso de quebrada Tulán (II Región, Chile). Unpublished Licenciate dissertation, Universidad de Chile.

López, P., I. Cartajena \& L. Núñez. 2013. Análisis de isótopos estables en colágeno de huesos de camélidos de Quebrada Tulán, Puna de Atacama, periodo Formativo Temprano (ca. 3.100-2.400 a.p.). Chungara 45: 237-47. https://doi.org/ $10.4067 / S 0717-73562013000200003$

Makowski, K. 2005. La religión de las altas culturas de la costa del Perú prehispánico, in M. Marzal (ed.) Religiones andinas: 39-88. Madrid: Trotta.

McRostie, V. 2007. La transición arcaico-formativa en la quebrada de Tulán, sur del Salar de Atacama, Chile. Evidencias arqueobotánicas. Unpublished Licenciate dissertation, Universidad de Chile.

- 2013. The role of plant production in subsistence and cultural changes during the Formative period in the Atacama Puna, southern Andes, Chile (1400 $\mathrm{BC}-500 \mathrm{AD})$. A re-evaluation based on the analyses of microfossils attached to hoes and grinding tools, and isotopic analyses of human bones. Unpublished $\mathrm{PhD}$ dissertation, University College London.

Moore, J. 2014. A prehistory of South America: ancient cultural diversity on the least known continent. Boulder: University Press of Colorado.

NúNEEZ, L. \& C. SAntoro. 2011. El tránsito arcaico-formativo en la Circumpuna y Valles Occidentales del Centro Sur Andino: hacia los cambios 'neolíticos' Chungara 43(1): 487-530.

Núñez, L., I. Cartajena, C. Carrasco, P. de Souza \& M. Grosjean. 2006. Emergencia de comunidades pastoralistas formativas en el sureste de la Puna de Atacama. Estudios Atacameños 32: 93-117. https://doi.org/10.4067/s071810432006000200008

(C) Antiquity Publications Ltd, 2017 
Núñez, L., V. McRostie \& I. Cartajena. 2009a. Consideraciones sobre la recolección vegetal y la horticultura durante el formativo temprano en el sureste de la cuenca de Atacama. Darwiniana 47(1) 56-75.

Núñez, L., I. Cartajena, P. de Souza \& C. Carrasco. 2009b. Temprana arquitectura ceremonial en la Puna de Atacama (Norte de Chile). Andes 7: 459-90.

Núñez, L., I. Cartajena \& C. Carrasco. 2011. Aldeas formativas tempranas de la quebrada Tulán: su naturaleza, articulación y disolución en el escenario Circumpuneño y Centro Sur Andino (1200-400 A.C.). Report prepared for Fondecyt 1070040, Santiago.

Núñez, L., I. Cartajena \& M. Grosjean. 2013. Archaeological silence and eco-refuges: arid events in the Puna of Atacama during the Middle Holocene. Quaternary International 307: 5-13. https://doi.org/10.1016/j.quaint.2013.04.028

Núñez, L., I. Cartajena, C. Carrasco, P. López, F. Rivera, P. De Souza, B. Santander \& R. Loyola. 2016. Nuevas excavaciones en Tulán-54: revelando la arquitectura ceremonial durante el Formativo Temprano de la Puna de Atacama. Revista Chilena de Antropología 34: 65-79.

Núñez, L., I. Cartajena, C. Carrasco, P. López, F. Rivera \& P. DE Souza. 2017. Nuevas excavaciones en el centro ceremonial de Tulán-54: entendiendo la arquitectura sagrada/profana durante el Formativo Temprano de la Puna de Atacama. Chungara 49(1): 3-33.

Pimentel, G., C. Rees, P. de Souza \& L. Arancibia. 2011. Viajeros costeros y caravaneros. Dos estrategias de movilidad en el periodo formativo del desierto de Atacama, Chile, in L. Núñez \& A. Nielsen (ed.) En ruta. Arqueología, historia y etnografía del tráfico sur andino: 43-81. Córdoba: Brujas.

Pollock, S. 2015. Towards an archaeology of commensal spaces. An introduction, in S. Pollock (ed.) Between feasts and daily meals: toward an archaeology of commensal spaces: 7-28. Berlin: Topoi.

Ponce SANginés, C. 1970. Las culturas Wankarani y Chiripa y su relación con Tiwanaku (Publicación 25). La Paz: Academia Nacional de Ciencias de Bolivia.
RodDick, A.P. 2002. Archaeological approaches to ritual in the Andes: a ceramic analysis of ceremonial space at the Formative period site of Chiripa, Bolivia. Unpublished MA dissertation, University of British Columbia.

RösING, I. 1994. La deuda de ofrenda: un concepto central de la religión andina. Revista Andina 12: 191-215.

SAntander, B. 2014. Bone tools use-wear in an Early Formative pastoralist site of northern Chile: weaving and piercing at the dawn of herds, in J. Marreiros, N. Bicho \& J. Gibaja Bao (ed.) International Conference on Use-Wear Analysis. Use-Wear 2012: 551-60. Newcastle: Cambridge Scholars.

Sinclaire, C., M. Uribe, P. Ayala \& J. González. 1998. La alfarería del período Formativo en la región del Loa superior: sistematización y tipología, in Sociedad Chilena de Arqueología (ed.) Actas del XIV Congreso Nacional de Arqueología Chilena: 285-314. Copiapó: El Congreso.

Soto, C. 2006. Cuentas de collar en la quebrada de Tulán. Características y diferencia entre los períodos arcaico y formativo. Unpublished professional practice dissertation, Universidad de Chile.

Stanish, C. 2003. Ancient Titicaca. The evolution of complex society in southern Peru and northern Bolivia. Berkeley: University of California Press. https://doi.org/10.1525/california/9780520232457 .001 .0001

Tarragó, M. 1989. Contribución al conocimiento arqueológico de las poblaciones de los oasis de San Pedro de Atacama en relación con los otros pueblos puneños, en especial el sector septentrional del valle Calchaquí. Unpublished PhD dissertation, Universidad Nacional de Rosario.

Thomas, C., A. Benavente, I. Cartajena $\&$ G. Serracino. 1995. Topater un cementerio temprano; una aproximación simbólica. Hombre y Desierto 9: 159-70.

VARELA, V. 2011. Análisis de seis fragmentos cerámicos de Tulán 54, quebrada de Tulán, Puna de Atacama. Report prepared for Fondecyt 1070040, Santiago.

Verano, J.W. 2001. The physical evidence of human sacrifice in ancient Peru, in E. Benson \& A. Cook (ed.) Ritual sacrifice in ancient Peru: 165-84. Austin: University of Texas Press.

Received: 31 May 2016; Accepted: 15 September 2016; Revised: 8 November 2016 